\title{
Pengembangan Buku Ajar Fisika Dasar I Berbasis Self Regulated Learning Sebagai Upaya Memotivasi Mahasiswa untuk Belajar Mandiri
}

\author{
Habibi $^{1}$, Lovy Herayanti ${ }^{2}$ \\ ${ }^{1}$ Program Studi Pendidikan Fisika IKIP Mataram, ${ }^{2}$ Program Studi Pendidikan Fisika IKIP Mataram \\ Pendidikan Fisika IKIP Mataram, NTB, 83125 \\ Email: habibi27021983@yahoo.com
}

\begin{abstract}
Abstrak: Penelitian bertujuan untuk menghasilkan buku ajar Fisika Dasar I yang berbasis self regulated learning yang dapat memotivasi mahasiswa di dalam belajar mandiri. Metode penelitian yang digunakan yaitu Development and Research dengan mengadopsi tahapan model pengembangan $4 D$ yaitu Define (pendefinisian), Design (perancangan), Develop (pengembangan) dan disseminate (penyebarluasan). Tahap Define dilakukan untuk menentukan karakteristik produk buku ajar yang dikembangkan melalui studi pendahuluan. Pemilihan format pembuatan buku ajar dilakukan pada tahap Design untuk menghasilkan draft I. Tahap Develop dilakukan untuk menghasilkan draft II, draft III, dan produk akhir dari buku ajar yang dikembangkan. Draft II diperoleh melalui hasil revisi validasi ahli yang direkomendasikan. Draft III merupakan hasil yang diperoleh dari uji kelompok kecil diambil secara random. Produk akhir pengembangan diperoleh dari hasil uji lapangan pada mahasiswa yang sedang menempuh mata kuliah Fisika Dasar I. Hasil validasi buku ajar serta perangkat pendukungnya menunjukkan kriteria "sangat layak" untuk digunakan serta dapat memotivasi belajar mahasiswa secara mandiri.
\end{abstract}

\section{Kata Kunci: Self Regulated Learning}

\section{Pendahuluan}

Mahasiswa dituntut untuk mampu memahami fenomena-fenomena di dalam fisika yang terjadi melalui kajian ilmiah dan disesuaikan dengan cara belajar mereka masing-masing, bukan hanya melihat berbagai fenomena menjadi sebuah kebiasaan saja tanpa memahami konsep sebenarnya yang terjadi. Setelah memahami fenomena tersebut maka, akan memudahkan seseorang untuk dapat berpikir lebih luas untuk mengembangkan ide-ide baru sebagai hasil dari sebuah kreatifitas berpikir di dalam proses pembelajaran ilmiah. Keberhasilan seseorang adalah tergantung dari cara mereka mempelajarinya dan tidak terlepas dari penguasaan konsep yang melekat pada masing-masing peserta didik

Self regulated learning ( $S R L$ ) adalah proses yang membantu seseorang dalam mengelola pikiran, perilaku, dan emosi agar berhasil menavigasi pembelajaran dan pengalaman mereka. Proses ini terjadi ketika tindakan seseorang dan prosesnya diarahkan pada perolehan informasi atau keterampilan, Zumbrunn, S. [7] Pembelajaran mandiri melalui $S R L$ terjadi ketika mahasiswa mengaktifkan dan mempertahankan kognisi dan perilaku secara sistematis serta berorientasi pada pencapaian tujuan pembelajaran, Zimmerman, et al. [6]. SRL mencakup beberapa aspek kognitif antara lain 1) Aspek "Perencanaan", dalam hal ini dapat dilakukan dengan mengorganisasi langkah-langkah yang meliputi penetapan tujuan melalui identifikasi tujuan-tujuan yang ingin dicapai, 2) Aspek

"Monitoring" dapat dilakukan dengan cara melibatkan kemampuan mengobservasi, melaporkan, dan mengukur kemajuan terhadap tujuan yang ingin dicapai, 3) Aspek "Mengevaluasi" dalam hal ini meliputi evaluasi tujuan untuk melihat kemajuan melalui hasil evaluasi tersebut, 4) Aspek "Memperkuat (reinforming)", merupakan refleksi dan pemberian penghargaan yang termasuk pula pemberian reward bagi peserta didik, Nono H. Y. ${ }^{[2]}$

Omid Tabatabaei dan Golnaz Arjmand [3] meneliti tentang hubungan $S R L$ dengan strategi dalam motivasi dalam pembelajaran menemukan bahwa dari 70 orang siswa memiliki kelemahan dalam menggunakan strategi $S R L$ tanpa adanya motivasi tersendiri untuk membuat kemajuan dalam belajar tetapi tidak berarti cukup dengan salah satunya saja. Hasil penelitian tersebut menjelaskan dengan jelas bahwa tanpa adanya motivasi pada seseorang maka akan mempengaruhi cara belajarnya. Adapun klasifikasi dari indikator motivasi belajar tersebut diantaranya adalah: hasrat dan keinginan untuk berhasil, dorongan dan kebutuhan di dalam belajar, harapan dan cita-cita untuk masa depan, penghargaan di dalam belajar, kegiataan yang menarik dalam belajar, lingkungan belajar yang kondusif sehingga memungkinkan seorang untuk dapat belajar dengan baik, Uno, Hamzah, B. ${ }^{[5]}$

Strategi SRL ini dapat terapkan di dalam pembelajaran di kelas melalui buku ajar yang digunakan sebagai pegangan utama. Hasil penelitian yang telah dilakukan oleh Ellianawati, S. Wahyuni ${ }^{[1]}$ 
dalam mengembangkan bahan ajar matematika berbasis SRL menunjukkan adanya peningkatan pemahaman dan hasil belajar yang signifikan.

\section{TINJAUAN PUSTAKA}

\section{A. Model Pengembangan $4 \mathrm{D}$}

Model pengembangan yang ditawarkan oleh Thiagarajan, S., et al. ${ }^{[4]}$ adalah Four $-D$ Model atau sering disebut dengan model 4-D yaitu : Define, Design, Develop, dan Disseminate. Empat tahap tersebut dapat digunakan sebagai acuan dari model pengembangan perangkat pembelajaran oleh pendidik.

Berdasarkan kedua pendapat di atas dapat diberikan inti dari penelitian pengembangan pendidikan tersebut yaitu "suatu proses yang dilakukan untuk menghasilkan produk berupa materi ajar atau seperangkat tujuan tertentu melalui validasi untuk memperoleh hasil yang lebih efektif dan berkualitas".

Sedangkan di dalam penelitian ini akan digunakan model pengembangan 4- $D$ sebagai salah satu alternatif bahan acuan untuk memperoleh bahan ajar yang efektif. Secara umum langkah-langkah pengembangan yang diberikan oleh model $4-D$ ini lebih banyak diberikan mengenai langkah-langkah pengembangan yang melalui validasi disain daripada eksperimen, sehingga lebih difokuskan dengan produk pengembangan. Adapun langkah-langkah pengembangan yang telah diadopsi pada model $4-D$ ini dapat dilihat pada gambar (3.1).

Adapun penjelasan mengenai masing-masing tahap pada pengembangan model $4-D$ ini menurut Thiagarajan, S. ${ }^{[4]}$ adalah sebagai berikut:

\section{Tahap Pendefinisian / Define}

Tahap pendefinisian ini dilakukan untuk menentukan dan menetapkan syarat-syarat pembelajaran yang akan dilakukan. langkah-langkah yang diberikan pada tahap ini yaitu :

a. Pra Penelitian yang bertujuan untuk mengetahui masalah yang bersifat urgent di dalam mengembangkan bahan pembelajaran. Hal-hal yang terkait untuk dipertimbangkan pada pra penelitian ini mencakup analisis kebutuhan, karakteristik mahasiswa dan materi, serta kurikulum untuk menentukan kebutuhan dan solusi untuk mendukung perangkat pembelajaran khususnya pada kajian yang diangkat sebagai masalah yang dihadapi pengajar. Selanjutnya terkait dengan teori belajar, yaitu teori-teori yang mendasari pengembangan yang diesuaikan dengan tuntutan ke depan yang semakin penuh dengan persaingan.

b. Analisis mahasiswa. Analisis mahasiswa merupakan kajian tentang latar belakang pengetahuan dan kognitif sebagai bekal awal di dalam pembelajaran baik dilihat dari segi produk, proses, ataupun psikomotornya. Hal ini yang akan dijadikan sebagai dasar pengembangan bahan pembelajaran untuk menyiapkan materi pembelajaran melalui ciri khas mahasiswa maupun pengalaman secara individu dan kelompok di dalam proses belajar. Analisis mahasiswa yang dilakukan meliputi kemampuan akademik, motivasi dalam belajar, serta kemampuan berpikir di dalam proses pembelajaran dari masing-masing mahasiswa.

c. Analisis Materi dan Tugas. Analisis tugas ini dilakukan adalah untuk menentukan kualitas konten dari satuan pembelajaran. Analisis tugas ini mencakup analisis struktur isi dan prosedural yang disesuaikan dengan kemampuan peserta didik.

d. Perumusan Tujuan pengembangan. Perumusan tujuan ini merupakan dasar dari penyusunan / perancangan sebuah perangkat pembelajaran yang telah tercantum pada kompetensi dasar. Perumusan tujuan ini juga sebagai dasar untuk merumuskan tes, pemilihan media, dan metode yang dipilih. Perumusan tujuan di sini akan disesuaikan dengan keterampilan berpikir dan cara belajar mahasiswa umumnya.

2. Tahap Perancangan / Design

Pada tahap perancangan dilakukan untuk membuat sebuah prototipe dari produk pengembangan. Tahap perancangan ini didahului dengan perumusan tujuan yang telah ditetapkan. Pada tahap perancangan ini diberikan empat langkah yang diantaranya yaitu :

a. Penyusunan tes acuan patokan. Berdasarkan tujuan dari pembelajaran yang dugunakan menjadi tolok ukur dalam mengukur kemampuan mahasiswa berupa hasil belajar dari proses berpikir mereka selama kegiatan pembelajaran berlangsung.

b. Pemilihan media pendukung. Penggunaan media ini bertujuan sebagai pendukung di dalam proses penyampaian pesan ke peserta didik. Pemilihan media ini disesuaikan dengan materi yang disampaikan.

c. Pemilihan format. Pada langkah ini dilakukan dengan memilih perangkat melalui kajian bahan pendukung dari berbagai referensi yang sesuai untuk menyesuaikan materi yang disajikan.

d. Desain awal perangkat pembelajaran. Desain awal perangkat ini berkaitan dengan proses hasil pengembangan perangkat pembelajaran melalui penulisan teori-teori yang terkait, penelusuran sumber-sumber referensi pendukung, serta modifikasi perangkat yang menghasilkan draft perangkat pembelajaran yang pertama. 
3. Tahap Pengembangan (develop)

Pada tahap ini dihasilkan draft perangkat pembelajaran yang ke dua dari perangkat pembelajaran yang dibuat dan telah melalui tahap validasi dari para pakar yang terkait. Tahap ini terdiri dari dua langkah diantaranya yaitu :

a. Validasi pakar. Pada langkah ini, draft yang pertama yang telah dihasilkan harus melalui validasi yang bertujuan untuk memberikan perbaikan-perbaikan dari kekurangan yang ada. Validasi pakar di sini dapat dilakukan oleh dosen pembimbing, dosen ahli, ataupun dosen pengampu, serta orang yang berkompeten dibidang perangkat pembelajaran. Validasi yang dilakukan oleh para pakar berupa koreksi dari semua perangkat pembelajaran yaitu buku ajar, assesmen, dan instrumen pendukung lainnya. Hasil dari revisi pakar tersebut dijadikan sebagai draft II yang akan melalui tahap selanjutnya.

b. Uji coba terbatas dan uji lapangan. Tahap uji coba terbatas ini dilaksanakan untuk mengontrol keefektifan, keterlaksanaan perangkat, ketepatan waktu, serta yang lainnya. Hasil yang diperoleh dari tahap ini akan digunakan sebagai bahan masukan, koreksi serta perbaikan untuk melengkapi kekurangan-kekurangan yang ada pada draft II. Hasil revisi yang berupa masukan dan saran tersebut dijadikan draft III yang akan diuji cobakan pada tahap berikutnya yaitu uji coba lapangan (the fact). Uji coba lapangan merupakan tahap implementasi dari perangkat pembelajaran sesuai dengan kurikulum yang diterapkan. Kegiatan ini bertujuan untuk mengetahui sejauh mana efektifitas dari perangkat pembelajaran di dalam kelas sesungguhnya. Efektivitas ini dapat dipantau dari hasil pengamatan berupa aktifitas mahasiswa serta dari tes hasil belajar mereka.

\section{Tahap Disseminate}

Pada tahap ini buku ajar yang telah dikembangkan akan digunakan untuk skala yang lebih luas misalnya di jurusan lain ataupun di perguruan tinggi lainnya. Tahap ini bertujuan untuk menguji efektivitas penggunaan buku ajar secara umum di dalam proses pembelajaran. Namun, karena keterbatasan waktu dan dana sehingga penelitian ini hanya dibatasi pada uji coba lapangan terbatas saja.

\section{B. Konsep Self Regulated Learning}

Self regulate learning adalah proses yang membantu siswa dalam mengelola pikiran, perilaku, dan emosi agar berhasil menavigasi pembelajaran dan pengalaman mereka. Proses ini terjadi ketika tindakan siswa dan prosesnya diarahkan pada perolehan informasi atau keterampilan, Zumbrunn, S. ${ }^{[7]}$
Berdasarkan beberapa gambaran dari berbagai sumber tersebut di atas dapat disimpulkan bahwa Self regulated learning dapat didefinisikan sebagai cara seseorang di dalam memonitor, mengontrol, mengarahkan aspek-aspek proses kognitif dan afektifnya untuk mendapatkan hasil belajar yang diinginkan. Self regulated learning mencakup beberapa aspek kognitif antara lain: Perencanaan, Monitoring, Mengevaluasi, dan Memperkuat (reinforming).

Tabel 1 Hubungan aspek kognitif dan aspek proses dalam $S R L$

\begin{tabular}{|c|c|c|}
\hline No & Aspek Kognitif & Aspek Proses \\
\hline \multirow[t]{3}{*}{1.} & Perencanaan & $\begin{array}{l}\text { Menetapkan tujuan yang } \\
\text { ingin dicapai }\end{array}$ \\
\hline & & $\begin{array}{l}\text { Menentukan strategi untuk } \\
\text { mencapai tujuan }\end{array}$ \\
\hline & & $\begin{array}{l}\text { Memonitor langkah-langkah } \\
\text { untuk mencapai tujuan }\end{array}$ \\
\hline \multirow[t]{2}{*}{2.} & Monitoring & $\begin{array}{l}\text { Menyusun kembali instruksi } \\
\text { yang dilakukan. }\end{array}$ \\
\hline & & $\begin{array}{l}\text { Menggunakan waktu yang } \\
\text { efisien (fokus pada tujuan). }\end{array}$ \\
\hline 3. & Evaluasi & $\begin{array}{l}\text { Mengevaluasi tujuan untuk } \\
\text { melihat kemajuan yang } \\
\text { dicapai }\end{array}$ \\
\hline 4. & $\begin{array}{l}\text { Penguatan } \\
\text { (reinforming) }\end{array}$ & $\begin{array}{l}\text { Melihat hubungan kausalitas } \\
\text { tujuan dan hasil yang } \\
\text { diperoleh untuk menyiapkan } \\
\text { strategi selanjutanya. }\end{array}$ \\
\hline
\end{tabular}

\section{METODE PENELITIAN}

Penelitian ini dilaksanakan di Jurusan Pendidikan Fiska IKIP Mataram. Jenis penelitian yang digunakan dalam penelitian ini merupakan penelitian pengembangan (4D model). Model pengembangan yang digunakan dalam penelitian ini mengadopsi tiga dari empat tahap pengembangan yang dikembangkan oleh Sivasailam Thiagarajan (1974). Model pengembangan ini meliputi tahap Define (pendefinisan), Design (perancangan), Develop (pengembangan), dan Disseminate (penyebarluasan). Pada tahap Define dilakukan studi pendahuluan yang terdiri dari analisis kebutuhan, analisis materi, dan analisis tujuan pengembangan. Tahap Design dilakukan untuk menetapkan format pembuatan buku ajar sesuai dengan yang telah distandarkan sehingga menghasilkan Draft I. Tahap Develop dilakukan 
untuk menghasilkan Draft II, Draft III, dan produk akhir buku ajar yang dikembangkan. Draft II merupakan hasil validasi dari ahli yang direkomendasikan. Uji coba terbatas dilakukan pada mahasiswa yang telah menempuh matakuliah Fisika Dasar I dan dipilih secara random sehingga menghasilkan Draft III. Produk akhir buku ajar yang dikembangkan dihasilkan dari hasil uji coba lapangan dan dilakukan pada kelas sebenarnya yang diambil dari Mahasiswa yang sedang mengikuti mata kuliah Fisika Dasar I TP 2016/2017. Adapun tahap-tahap pengembangan dapat dilihat pada gambar di bawah ini.

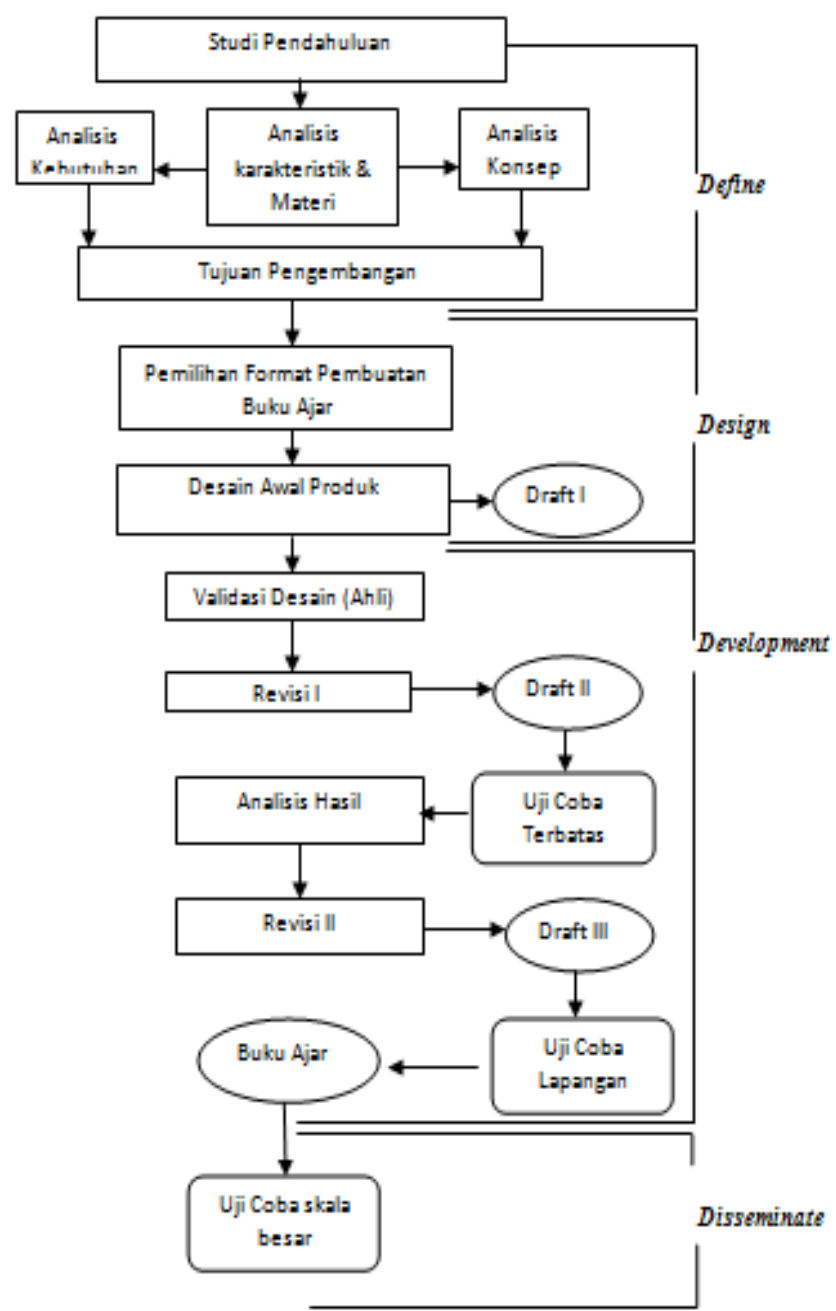

Gambar 1. Model Pengembangan 4D, Sivasailam, T. (1974)

\section{HASIL DAN PEMBAHASAN}

\section{Define}

Materi yang dikembangkan melalui studi pendahuluan ini merupakan hasil dari studi pustaka untuk silabus yang umumnya dipakai di perguruan tinggi. Materi yang diperoleh selanjutnya dikonsultasikan dengan dosen pengampu mata kuliah Fisika Dasar I kemudian disebarkan pula melalui angket kepada mahasiswa yang telah selesai menempuh mata kuliah tersebut untuk memperkuat materi yang dikembangkan. Materi yang diperoleh dari hasil studi awal antara lain yaitu :

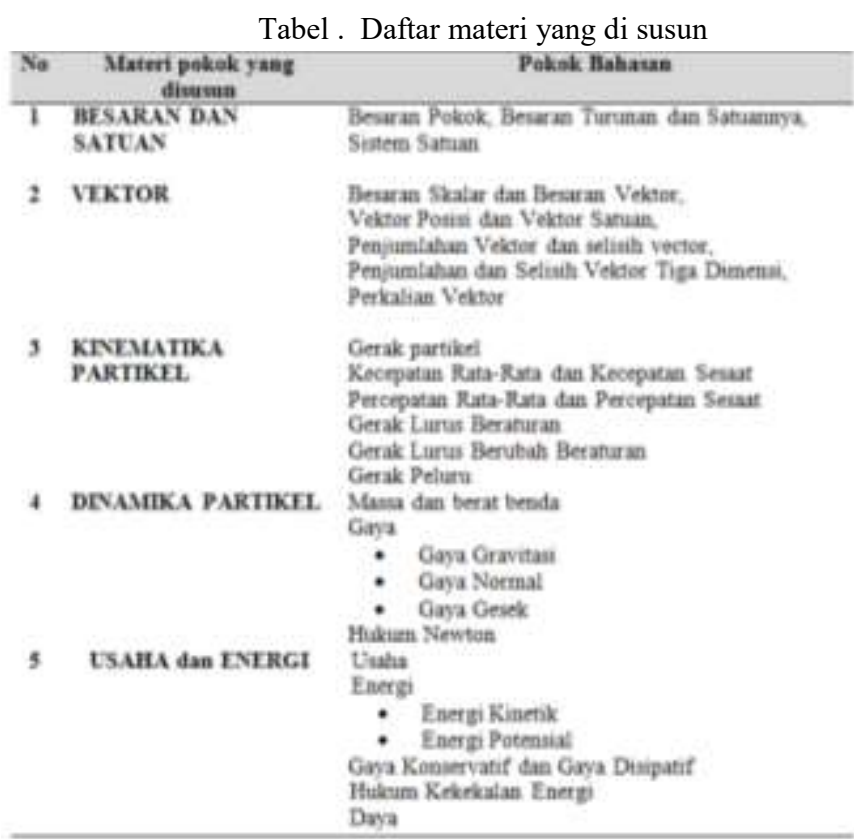

Design

Sedangkan berdasarkan hasil validasi ahli yang dilakukan diperoleh hasil dengan skor rata-rata masing-masing untuk aspek kelayakan isi 3,67 dengan kategori "Sangat baik", aspek kebahasaan 3,33 dengan kategori "sangat baik", aspek penyajian 3,24 berkategori "baik", dan aspek kegrafikan dengan skor 3,33 berkategori "sangat baik".

Hasil validasi yang diperoleh bertujuan untuk memperoleh kualitas buku ajar yang lebih baik sehingga dapat dinyatakan siap untuk di ujicobakan selanjutnya.

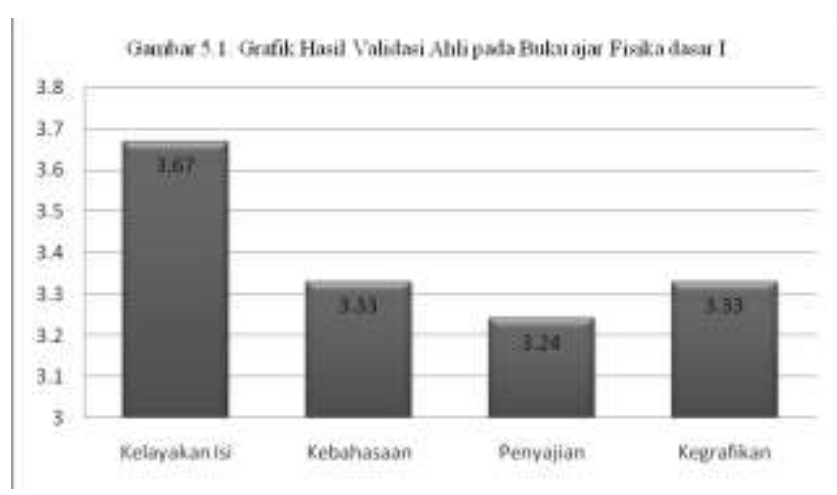

\section{Develop}

Hasil penelitian menunjukkan bahwa Mahasiswa yang memiliki kemampuan rendah ternyata memiliki kemampuan rendah untuk mengatur cara belajarnya sendiri (SRL) (tabel 2). Hal ini terlihat dari hasil angket $S R L$ yang disebarkan sebelum menggunakan buku ajar dan hasil tes kemampuan awal yang diperoleh. 


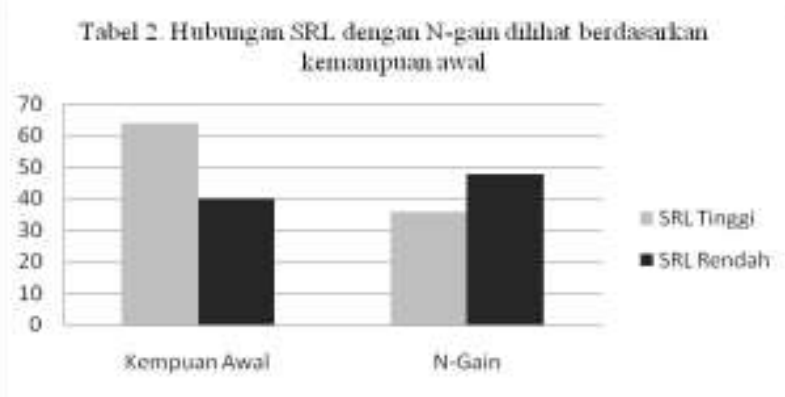

Hal ini berarti terdapat pengaruh buku ajar berbasis $S R L$ yang digunakan untuk mengatur cara belajar mereka secara mandiri. Mahasiswa yang memiliki kemampuan awal dan SRL tinggi mengalami peningkatan nilai rendah. Hal ini disebabkan karena perbedaan nilai antara kemampuan awal dengan akhir tidak terlalu besar karena nilai awalnya yang tinggi.

\section{PENUTUP}

Hasil pengembangan produk buku ajar Fisika Dasar I diperoleh lima materi yang telah disetujui untuk dituangkan dalam isi produk yang dikembangkan, yaitu; Besaran dan Satuan, Vektor, Kinematika Partikel, Dinamika Partikel, serta Usaha dan Energi. Berdasarkan hasil ujicoba lapangan didapatkn bahwa buku ajar Fisika Dasar I berbasis $S R L$ memberikan pengaruh yang positif terhadap kemampuan belajar mandiri mahasiswa.

\section{UCAPAN TERIMA KASIH}

Ucapan terima kasih diucapkan kepada DP2M DIKTI sebagai pihak yang telah membiayai penelitian ini.

\section{REFERENSI}

${ }^{[1]}$ Ellinawati, S. W. (2012). Pengembangan Bahan Ajar Fisika Matematika Berbasis Self Regulated Learning Sebagai Upaya Peningkatan Kemampuan Belajar Mandiri. Jurnal Pendidikan Fisika Indonesia, Vol. 8, 33-40

${ }^{[2]}$ Nono H. Y. (2010). Hubungan antara Selfregulated Learning dengan Self-efficacy pada Siswa Akselerasi Sekolah Menengah Pertama di Jawa Timur. Fakultas Psikologi UNAIR. INSAN, Vol 12, No. 02

${ }^{[3]}$ Omid Tabatabaei dan Golnaz Arjmand (2013). The Relationship of Self-Regulated Learning and Motivational Learning Strategies with Intermediate EFL Learners' Achievement. Life Sci J Vol.10 (1s) No. 177-181
${ }^{[4]}$ Thiagarajan, S., et al. (1974). Instructional Development for Training Teachers of Exceptional Children "A Sourcebook". Indiana University Bloomington : Indiana

${ }^{[5]}$ Uno, Hamzah, B. 2008. Teori Motivasi dan Pengukurannya. Jakarta: PT. Bumi Aksara.

${ }^{[6] Z e m m e r m a n ~ J . ~ B . ~ e t ~ a l . ~(2002) . ~ B e c o m i n g ~ S e l f-~}$ Regulated Learner: and Overview. Colloge of Education, The Ohio State University, Theory Into Practice, Vol. 41 No. 2, 64-70. Diakses tanggal 1910-2013

${ }^{[7] Z u m b r u n n, ~ S . ~ e t ~ a l . ~(2011) . ~ E n c o u r a g i n g ~ S e l f-~}$ Regulated Learning in the Classroom: A Review of the Literature. Metropolitan Educational Research Consortium (MERC) : Virginia Commonwealth University. Diakses tanggal 19-10-2013

\section{Biografi Penulis}

Habibi, M. Pd. Lahir di Lombok Tengah pada tanggal 27 Pebruari 1983. Gelar Sarjana Fisika diperoleh pada Program sarjana di Universitas Negeri Yogyakarta tahun 2008 dan melanjutkan kembali pada program Pascasarjana Pendidikan IPA UNRAM tahun 2012. Saat ini masih mengabdi sebagai Dosen tetap pada institusi pendidikan IKIP Mataram. Pengalaman di bidang riset terfokus pada kajian permasalahan dunia pendidikan fisika. Riset-riset yang telah dilakukan berupa riset dibidang internal, riset untuk Dosen Pemula (PDP), dan riset untuk hibah bersaing.

Lovy Herayanti, M.Pd. Lahir di Mataram pada tanggal 3 Juni 1981. Gelar Sarjana Pendidikan Fisika diperoleh pada Program sarjana di Universitas Mataram tahun 2003 dan melanjutkan kembali pada program Pascasarjana UPI dibidang Pendidikan tahun 2007. Saat ini masih mengabdi sebagai Dosen tetap pada institusi pendidikan IKIP Mataram. Pengalaman di bidang riset terfokus pada kajian permasalahan dunia pendidikan. Riset-riset yang telah dilakukan berupa riset dibidang internal, riset untuk Dosen Pemula (PDP), dan riset untuk hibah bersaing. 